\title{
Cikkismertetés: Az egészségműveltség osztályozása mesterséges intelligencia használatával
}

\author{
Article review: Classifying health literacy with machine learning
}

Ismertető: $\quad$ Osváth Mátyás $\square$

Debreceni Egyetem, Általános Orvostudományi Kar, Egészségtudományok Doktori Iskola, Debrecen

Ismertetett cikk: Balyan R, Crossley SA, Brown W, et al. Using natural language processing and machine learning to classify health literacy from secure messages: The ECLIPPSE study. PLoS ONE, 2019;14(2):1-17. doi: 10.1371/journal.pone.0212488

Beküldve: $\quad$ 2020.09.03.

doi: $\quad$ 10.24365/ef.v61i4.632

Kulcsszavak: egészségmúveltség; NLP; természetes nyelvfeldolgozás; gépi tanulás; nyelvelemzés

Keywords: health literacy; NLP; natural language processing; machine learning; linguistic analysis

\section{ELMÉLETI ÁTTEKINTÉS}

A krónikus betegségek (pl. cukorbetegség) kezelése összetett feladat, és gyakori kommunikációt igényel a páciens és az egészségügyi dolgozók között.

A hiányos egészségműveltség csökkenti az ellátás eredményességét, ami növeli az állapotromlás, a szövődmények és a halálozás esélyét. A nem megfelelő kommunikáció és csökkent terápiahűség is hozzájárulhat - az egyébként elkerülhető - szenvedéshez és az egészségügyi költségek növekedéséhez.

A betegeknek szóló online portálok, a köznyelvben betegportálok olyan biztonságos weboldalak, amelyeken a páciensek és az egészségügyi dolgozók felvehetik egymással a kapcsolatot, üzenetet válthatnak, valamint alkalmasak személyes egész- ségügyi információk (pl. kórházi látogatások időpontjainak, receptek, számlák és teszteredmények) tárolására.

Az elektronikus egészségügyi információkkal rendelkező, online betegportálok elősegítik a kommunikációt a páciens és az egészségügyi személyzet közötti üzenetváltások által, támogatást nyújtva a kórházi kezelések közötti időszakban is. A betegportálok használata javíthatja a terápiahúséget, az orvosbeteg kommunikációt és az ellátás igénybevételét.

Az online kommunikációra a beteg egészségműveltségének mértéke hatással van. Az utóbbi 5 évben a hiányos egészségmúveltséggel rendelkező páciensek között 65\%-os növekedés volt megfigyelhető a betegportálok használatában, összehasonlítva a megfelelő egészségmúveltségú páciensekkel, ahol a növekedés $41 \%$ volt. 
Az egészségmúveltség szintjét mérő jelenlegi kérdőívek sokszor önbevalláson alapulnak, és időigényesek lehetnek. Azonban a korábbi kutatások által alátámasztott természetes nyelvfeldolgozás (natural language processing, továbbiakban NLP) - a számítógépes nyelvészetet és gépi tanulást felhasználva - orvosi szakterületen is bizonyítottan alkalmazható és hatékony eszköz lehet, viszont egészségmúveltség mérésére még nem alkalmazták.

Az interjúk, kérdőívek használata helyett az automatizált szövegfeldolgozás hatékony lehet a különböző egészségmúveltséggel rendelkező személyek azonosításában, a személyre szabott intervenció és kommunikáció kialakításában nagyobb populációk esetén is.

A kutatás célja a cukorbetegek egészségműveltségük alapján hiányos és megfelelő kategóriákba sorolása számítógépes NLP segítségével, és a besorolás összehasonlítása a kérdőívvel felmért egészségmúveltséggel, illetve összevetése a betegek szocio-demográfiai jellemzőivel és kezelési eredményeivel. Amennyiben sikerül az automatizálható NLP-vel azonosítani a hiányos egészségmúveltségú betegeket, akkor a kezelőorvosnak való visszajelzés javíthatja a kommunikációt, és ezáltal az ellátás eredményességét.

\section{MÓDSZER}

Az adatokat a Kaiser Permanente Northern California (KPNC) Diabetes Registry adatbázisa szolgáltatta, ami több mint 150000 etnikailag különböző páciens és 9000 orvos 1 millió üzenetét tartalmazza. A páciensek egy csoportja $(n=14$ 357) egy korábbi kutatás során kitöltött, önbevalláson alapuló, egészségműveltséget mérő kérdőívet, aminek változóit ez a kutatás is felhasználta. Az üzenetek közül ( $n=$ 1050 577) a nem háziorvosnak és a nem angol nyelven írt üzeneteket kizárták.

Az üzenetek száma 2-től 205-ig (átlagosan 39,9 üzenet), valamint az egy beteg által írt szavak száma 1-től 16 469-ig terjedt (átlagosan 2059 szó), azonban az 50 szónál kisebb terjedelmú üzeneteket eltávolították. Az elemzésre felhasznált, megtisztított vizsgálati anyag 6941 páciensből és 283216 üzenetből állt.
A kutatásban alkalmazott NLP eszközöket olyan nyelvi jellegzetességek mérésére fejlesztették ki, ami kapcsolatba hozható az egészségmúveltséggel (pl. szövegkomplexitás, -kohézió, szintaktikai összetettség, akadémiai és orvosi szavak, szóismétlés).

A szocio-demográfiai változók (pl. kor, nem) és kezelési eredmények (kórházi felvétel, elégtelen gyógyszeradagolás, hipoglikémia) mellett 185 nyelvi jellemzőt nyertek ki az egészségműveltségi profil kialakítására.

A nyelvi változók közül kiemelhető a lexikális diverzitás (a szavak változatossága), valamint határozószavak, melléknevek és funkciószavak (pl. személyes névmás) gyakorisága, amelyek használata magasabb egészségmúveltségű személyekre jellemzőbb.

Az egészségmúveltséget mérő kérdőív állításaiból három, diszkrét (hiányos és megfelelő) függő változót alkottak, amiket a profilok besorolására használtak fel.

Az elemzést felügyelt gépi tanuláson alapuló modellekkel végezték a 185 nyelvi változón és a diszkrét változóvá alakított, egészségmúveltséget mérő indexeken. Az osztályozást a pontosság, érzékenység, specificitás, C-statisztika (ROC-görbe), pozitív és negatív prediktív érték jósági mutatókkal mérték.

A nyelvi jellemzők alapján kategóriába sorolt egészségműveltséget összehasonlították az önbevalláson alapuló egészségmúveltséggel, szocio-demográfiai státusszal és kezelési eredményekkel.

\section{EREDMÉNYEK}

A hiányos és megfelelő egészségmúveltségi profilok kategorizálása során a jósági mutatók megfelelőek voltak (szenzitivitás $=75,49 ;$ C-statisztika $=0,74$ ).

A szövegjellemzők vizsgálata során a hiányos egészségmúveltségú csoportba sorolt páciensekre a kisebb szószám és lexikai diverzitás (pl. több szóismétlés), valamint a kevésbé szofisztikált kifejezésmód (pl. konkrétság) volt jellemző; továbbá több negatív és kevesebb pozitív érzelmet kifejező szót 
használtak, és gyakrabban fogalmaztak harmadik személyben, mint első személyben.

A hiányos egészségmúveltségű kategóriába sorolt személyek életkora átlagosan 1-3 évvel volt több a mintában, 70,8-76,1\% volt nem-fehér, és 84,7$88,7 \%$ rendelkezett középfokú végzettséggel, összehasonlítva a megfelelő egészségmúveltségű csoportba sorolt személyekkel, akik között 59,9-63,5\% volt nem-fehér, és 93,4-95\% rendelkezett középfokú végzettséggel. Ezek az eredmények hasonlóak a kérdőíves módszerrel nyertekhez.

A hiányos egészségmúveltségúek osztályába sorolt személyek alacsonyabb terápiahúséggel $(p<0,047)$ és magasabb hipoglikémiás szinttel $(p<0,001)$, valamint jelentősen több komorbid kondícióval rendelkeztek a megfelelő egészségmúveltségű csoporthoz viszonyítva.

Az évenkénti járó- és fekvőbeteg, valamint a sürgősségi ellátás igénybevételének száma is többször fordult elő $(p<0,001)$ a hiányos egészségmúveltségúként kategorizált betegek körében.

\section{DISZKUSSZIÓ}

A korábbi kutatásokkal összhangban a modell a páciensek egyharmadát hiányos egészségműveltségűnek osztályozta.
A különböző nyelvi jellemzők (pl. kevésbé szofisztikált kifejezések, kevesebb pozitív szó) és gépi tanulási modellek elfogadható szinten jósolták be az önbevalláson alapuló egészségmúveltséget, amelyre építve kialakítható az eltérő egészségműveltségű személyek megkülönböztetésére alkalmas nyelvi profil.

A kutatás egyik korlátja, hogy csak azokat a pácienseket vizsgálták, akik a háziorvosuknak küldtek üzenetet, azonban a betegek egyharmadára nem jellemző az üzenetváltás általi kapcsolatfelvétel.

$A z$ egészségműveltség mérése kihívást jelenthet egyéni és populációs szinten, ezért egy automatizált szövegfeldolgozási módszer a nagy valószínűséggel hiányos egészségműveltséggel rendelkező személyek azonosításával hozzájárulhat az orvosi kommunikáció javításához, a krónikus betegségek szövődményeinek, előfordulásának és halálozásának csökkentéséhez.

Az orvos ezáltal figyelmeztetést kaphat arra, hogy adott betegnek nehézséget jelenthet a szóbeli és/vagy írásos tájékoztatások értelmezése, azaz az ilyen páciensek utánkövetésére nagyobb szükség lehet az orvosi tanácsok és a gyógyszeres kezelések betartása érdekében.

Ez az egyik legelső vizsgálat a nagy valószínűséggel hiányos egészségműveltséggel rendelkező és a kezelési eredmények szempontjából kockázatos személyek NLP általi azonosítására.

\section{TANULSÁGOK A HAZAI SZAKEMBEREK SZÁMÁRA}

A hiányos egészségmúveltség akadály a páciens és az ellátó közötti kommunikációban, és az optimális kezelési eredmények elérésében. Ennek elkerülésére az egészségügyi rendszerekben az előrejelző modellek alkalmazása növekszik, amely révén javulás érhető el populációs és individuális szinten, javítva a kommunikációt és intervenciót. A páciensek üzeneteiből kinyert szövegjellemzők alkalmasak lehetnek a különböző egészségműveltséggel rendelkező személyek megkülönböztetésére, ezáltal feltehetően kevesebb kérdőiv és felmérés kitöltésére lesz szükség, vagyis korszerűbb módszerrel az időigényes és költséges adatgyüjtés jelentős részben kiváltható. 